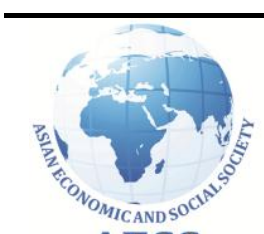

AESS
Asian Economic and Financial Review

$\operatorname{ISSN}(e)$ : 2222-6737/ISSN(p): 2305-2147

\title{
IMPACT OF EXCHANGE RATE IN THE RUN-UP TO EU ACCESSION: AN EMPIRICAL ANALYSIS OF REPUBLIC OF MACEDONIA
}

URL: www.aessweb.com

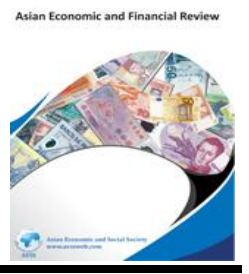

Tatjana Boshkov ${ }^{1 \dagger}$--- Gligor Bishev

${ }^{1}$ Assistant Professor at Faculty of Tourism and Business Logistics, University "GoceDelcev", Stip, Macedonia

${ }^{2}$ University Professor and Executive Director and Chairman of the Board, Sparkasse Bank, Macedonia

\section{ABSTRACT}

Because of the fact that South-eastern European countries rely mainly on exchange rate anchors to reduce inflation, the appreciation of the real exchange rate among countries in the region is significant, and it is slightly lower when it's compared with the EU member states. As a result, these countries suffer from loss of competitiveness. This can be clearly seen from the movements of the deficit on their current account, which is important in all these countries. Using the exchange rate as anchor for inflationary expectations, on long run it has been identified as effective, producing a low and stable inflation rates. Therefore, Macedonia needs to address important challenges through determined implementation of structural reforms to cope with competitive pressures and market forces within the EU. Progress with structural reform scan help for macroeconomic stability, for example, by reducing the structural external deficits. Also, it helps nominal convergence, as the productivity realizes the improvement of competitive ness and helps disinflation by maintaining low unit cost.In terms of macroeconomic convergence, EU membership requires convergence of the Macedonian economy with that of the EU in realistic conditions, indicating income per capita and economic structure, and in nominal terms, meaning convergence of prices, inflation and interest rates. In this paper, we focus on impact of exchange rate in small and open economy like Macedonia, to be seen in the context of continued integration of supply chains. Further we underline that membership into European Union can improve the situation of Macedonia only if the access to a large extent makes Macedonia location from which foreign investors can serve to the EU market,meaning that the domestic industry with the help of FDI must take the necessary change of its output. Also with the support of estimations, in this paper, we showed that in a small and open economy, such as Macedonia, using real exchange rate as an instrument could be realized the opportunity for growth of export performances, increasing aggregate demand and increasing economic growth thus speeding the convergence process to EU.

(C) 2015 AESS Publications. All Rights Reserved. 
Keywords: Convergence, Exchange rate, EU accession, Macedonia, Export, Growth.

\section{JEL Classification: F4.}

\section{Contribution/ Originality}

The study contributes to the existing literature in the sense that it used econometrics to estimate collected data and to analyze the causes that throw more light on how Macedonia can benefit from the type of exchange rate regime thus speeding the convergence process to EU.

\section{INTRODUCTION}

A survey provides an interesting over view of progress with real and nominal convergence in Central and South-Eastern Europe and the macroeconomic challenges that they face on their path to the EU (Schadler et al., 2005). Namely, referring to the macroeconomic stability and progress in transition both are closely related and both are important for sustainable growth and progress towards a functioning market economy. Progress with structural reform scan help for macroeconomic stability, for example, by reducing the structural external deficits. Also, it helps the nominal convergence, as the productivity realizes the improvement of competitiveness and helps disinflation by maintaining low unit cost. In a study describing experiences about the development in the newest EU members, Fidrmuc shows that the development in more successful transition countries reflects higher total factor of productivity than the growth in relative level so $f$ capital and labor (Fidrmuc, 2004). This underlines the importance of market-established reforms for development. Various indicators show that the most of the South eastern countries require continual progress in transition reforms to become functional market economies. In regards to structural reforms, if they remain slow, positive growth rates seen in the last five years in many South-eastern European countries may not be sustainable.Initial reforms - like trade and price liberalization, privatization in many countries, and relative macroeconomic stability - facilitated lessened development since 2000in many countries in the region.

\subsection{The Role of Exchange Rate as a Policy Matter}

As other countries do, Macedonia also is facing with two main challenges, because the fact that the EU agenda remains strategic priority for Macedonia. The first one is managing the continued and rapid process of future real economic convergence, which will come with high real GDP and productivity growth rates and large capital inflows. The second challenge is achieving the degree of nominal convergence, which is required to enter into European Monetary Union. Macedonia as part from SEE6 could draw experience from recent new EU member state with monetary framework during accession. Exchange rate regimes during accession had shown different variations. These variations indicated the importance of fundamentals and associated policies in the implementation and achievement of macroeconomic stability. Some of the recent EU members moved from fixed exchange rate to more flexible monetary policy as transition progressed.The appreciation of the real exchange rate among countries in the region is significant, 
regardless the exchange rate regime. Also, this underlines the importance of the fact that fiscal policy is important factor that influence the setup of monetary policy, while the adequate coordination of these policies is crucial for creation and maintenance of the macroeconomic stability. Reality showed that economic recovery continue to progress, but unemployment is still on high level. The renewed deterioration of fiscal discipline in 2013 and 2014 calls for improved budget planning procedures and better consistency of annual budget execution with the mediumterm fiscal strategy (Sedelmeier, 2006). Another fact is that FDI is growing up and this is very important for economy growth and export performances. The increase in the consumer price index (CPI) averaged $2.8 \%$ in 2013, down by about 0.5 percentage points since 2012 and fell further in spring 2014, mainly due to declining prices for food and housing and utilities (NBRM, 2014).

Like many countries in the early stages of transition, South-eastern European countries rely mainly on exchange rates to reduce the inflation. In many countries, exchange rate helps to reduce the inflation to lower single digits since 2004. Since 2000 Serbia has shifted between nominal and close to real exchange rate targeting (with important regime shifts in early 2003 and 2005) (De and Schnabl, 2004). South-eastern Europe can draw experience from recent new EU member states with monetary frame work duringaccession. Exchange rate regimes during accession had shown different variations, which indicate the importance of fundamentals and associated policies in the implementation and achievement of macroeconomic stability (Schadler et al., 2005). Some of the largest recent EU members gradually moved fromexchange-rate-based stabilizations to more flexible monetary policy as transition progressed. South-eastern Europe has much lower speed of reforms and lower growth rates. Related to this, capital inflows to the region are much smaller and have shown greater dispersion between countries. Regard less the exchange rate regime, the appreciation of the real exchange rate among countries in the region is significant. For example, the current account deficit in 2007 ranged from 3.1\% of GDP in Macedonia to 36.2\% of GDP in Montenegro (European Commission, 2007). In terms of high import dependence and the relativelyslowimplementationofstructuralreformsrealizedinincreasedexport potential, contributed for the importance of high trade deficit, which was largely financed by high private transfers (Dauti and Pollozhani, 2008).

\subsection{Macedonia's Challenges to Eu Accession}

The performances of the real convergence of Macedonia lag seriously compared with the new Member States. Although GDP growth is accelerating in Macedonia in the past few years, in comparative perspective Macedonian inability to maintain rapid convergence of GDP per capita with EU countries, is a source of concern (Holtemoller, 2005). Given low Macedonian GDP per capita, realizing real convergence in per capita income is increasingly important matter. Macedonia has suffered from regional instability and domestic disturbances, as other new members also faced with economic and financial crises (Bisev and Petkovski, 2003). The growth of capital stock is a key component of real convergence to new Member States, because the ratio of investment to GDP is higher in most of those new member states, which ranges between $35 \%$ and $25 \%$ of GDP. 
The investment rate of Macedonia is on average less than $20 \%$ of GDP, which made the per capita income convergence with the EU impossible, through the growth of the capital stock. If Macedonia isn't able to increase the share of GDP and to devote at fixed capital formation over $25 \%$, will be forced on fully devoting for productive gains, thus to be with the level of income per capita of other EU Member States. From the reports about economic policy it is clear that in January 2014, the authorities submitted the eighth Pre-accession Economic Programme (PEP), outlining key economic, fiscal and structural reforms for the period 2014-2016. Its macroeconomic and fiscal framework is somewhat optimistic with gradually increasing growth averaging close to 4 $\%$, driven by domestic demand in 2016. Analyzing macroeconomic stability, the current account deficit narrowed in 2013 to $1.8 \%$ of GDP, as the merchandise trade balance improved in spite of a drop in current transfers. In the same period, foreign direct investment (FDI) inflows strengthenedin 2013, they accounted for $3.5 \%$ of GDP, and stayed at the same level in the first half of 2014. In 2015 pick-up in export activity is expected, when the new capacities are taking up operations. It is important to mention that many of the larger rates of the capital formation in the new Member States is due to high levels of corporate savings and capital inflows, mainly in the form of FDI rather than result of high domestic personal savings. Thus, the low level of FDI in Macedonia is a reason for short-term decline in capital formation. Another barrier for investment - which carry growth - is domestic "investment deficit", which is mainly due to poor profitability and savings as the investment behavior of Macedonian companies too. Thus, the overcoming the low propensity for investing by the Macedonian firms is particularly important for real convergence (Habermas, 2012). Macedonia differs from the new Member States not only because of its low level of capital formation, but because of its different dynamics of total factor productivity as well. Because of the capital accumulation in Macedonia some minor contributions for development were required, such as changes in employment and in total factor productivity growth, which were the main driver of GDP growth as well, from one year to another. To formulate effective policy it is necessary to research the growth of total factor productivity in Macedonia, as well as the causes of low business investment. The other elements of the structural convergence are the movement of labor and economic activities, generally from agriculture to industry and services. In all transition economies this structural change is an ongoing process and it is a part of the international routes where all countries experience a shift in economic activity from agriculture to manufacturing and then from agriculture and manufacturing to the services, as the income per capita is increasing (Edwards, 1998). Lab our market conditions improved marginally, but remained challenging. The unemployment rate fell gradually, to $28.2 \%$ in the second quarter of 2014, from an average of 29 $\%$ in 2013. Reforms to tackle the structural rigidities of the lab our market have made only limited progress. The employability of workers should be improved through structural measures and better targeting of the active lab our market measures (Joseph and Bruce, 2008). Macedonian industrial value of added share is declining faster than in the case of new Member States, and in Macedonia's case, this structural change occurs with small convergence in per capita income. EU Membership can improve the industrial situation in Macedonia only if the access largely makes Macedonia a 
location from which foreign investors can serve the EU market and if the domestic industry, with the help of FDI can take the necessary change for its output, an issue explored in greater detail in the section of the industry.

\subsection{Convergence in Terms of a Fixed Exchange Rate Regime}

In terms of macroeconomic convergence, EU membership requires convergence of the Macedonian economy with the one of the EU, in context of realistic conditions - indicating per capita income and economic structure, and nominal terms - indicating convergence of prices, inflation rates and interest rates.Fiscal effects of accession: Strengthening the absorption capacity for using EU funds is of a great importance in order to get all available support in the pre-accession period before entering the EU. Also, preparation and simulation of financial flows between Macedonia and the EU budget before and after accession period is of a great importance in acquiring orientation magnitude of flows, as well as strengthening the administrative absorption capacity for using EU funds (Grigonyte, 2004b). This process should include activities aimed at increasing the capacity to prepare projects and activities aimed at strengthening the institutions and procedures that are necessary for effective absorption of EU funds. There is need of NGOs, schools, universities and individuals to help in developing the capacity for implementation and use of EU funds. Fiscal discipline and the quality of public spending deteriorated further in 2013 and 2014. During those two years the government was again forced to adopt a supplementary budget due to pressures arising from revenue shortfalls and repayment of accumulated arrears owed to private companies in the first half of the year. The government's medium-term strategy for 20142016 foresees a gradually declining general government deficit. Fiscal discipline needs to be improved, and there is significant scope for enhancing fiscal transparency. The government's fiscal consolidation plans need to be underpinned by concrete measures.

Industry and non-financial services: One of the conditions for Macedonia is to realize faster growth of GDP of the major investments and major engagements with the world economy, especially with neighboring countries in Southeast Europe and the EU. This may be the preference towards market-friendly reforms in improving business environment and attracting more FDI. Macedonian industry and industrial exports are less diversified than those of many not so huge new member states and Macedonia should promote diversification.

Macedonia needs to support the modernization and upgrading of its main established sectors such as textiles and metal products. Subsidies or state aid should improve the competitive environment. Macedonian industry must beef up research to strengthen Macedonia's ability of using and adapting new technology. Strengthening the capacity is reflected in the restructuring of infrastructure costs for transport, because statistics show their increased role. Also, there are reforms of the Macedonian Government, which are focused on developing tourism and attracting foreign tourists, something that everyone receives. Prepared formal plans for tourism development are achieved as their implementation too. Macedonia is well positioned as a safe and attractive destination, with improved infrastructure and services used by tourists, including hotels, 
restaurants, historical monuments, natural reserves, gradually making the country more accessible to visitors, particularly for aviation where relationships are rather limited (World Bank, 2013c). Agriculture: This segment is an issue that particularly affects Macedonia. The most important constraints which Macedonian agriculture and rural development are facing are wider structural problems in the market of final goods and services and rural market as a factor.

Financial Services and capital flows: Policymakers should be prepared for pressures of real convergence in accordance with EU membership. If there is pressure on the real appreciation or revaluation, current leaving de facto peg in service of fluctuating exchange rates should be considered too. Also, it is necessary to strengthen the regulatory and supervisory forces for macroeconomic stabilization and limit the risk of credit boom and crisis, as well as monitoring and discouraging foreign currency loans to households. It is necessary to regulate the cost of customer acquisition through insurance and pension funds, and efficiency in administration. Next recommendation from the experiences of other countries is creating a framework that will provide an opportunity for analysis, regulation and supervision of the financial system in a comprehensive manner, as uprising supervisory structure that will integrate all financial sectors in Macedonia together with the Central Bank. Macedonian banking-sector regulator should develop a comprehensive framework for the regulation of the liquidity management of local banks, including tools for potential restrictions on cross-border liquidity during the instability. For structured business environment is considered to hold an average level according to the analysis, in terms of overall assessment. The government is making efforts to improve attracting foreign investment in Macedonia during the past few years. Macedonia indicates improvement in terms of regulatory quality, business freedom, trade freedom and the financial sector. In practice many shortcomings continue to hamper business operations, i.e. areas with specific weaknesses which include excess bureaucracy, corruption and a weak significant protection of their rights. The development of the domestic economy depends on building better linkages between foreign investment companies and local businesses which, in turn, requires government and local businesses to work on better skillsmatching and investment in higher-productivity activities. Improvements in market entry and exit would also help.

Taking in view market entry and exit and the free economic zones, domestic companies do not enjoy a level playing field with foreign companies as regards incentives. Conditions for obtaining public support implicitly favor (larger) foreign firms, as local firms can rarely meet the required investment size. Government arrears still pose a problem for business' liquidity, despite the recently tightened legal requirements. Overall, while setting up a business has become slightly easier, difficulties remain as regards obtaining permits.

Financial sector development: The country's financial system is dominated by the banking sector, about $89 \%$ of the system's total assets, while the insurance sector, including fully-funded pensions, represents roughly $4 \%$ of total assets (De and Gerard, 2006). Macedonia's banking sector is seen as solid, according to the IMF. The size of banks' financial intermediation is important, with the assets-to-GDP ratio having risen gradually over recent years to about $80 \%$ by 
the end of the first quarter 2014. The financial system remains stable, and supervisory capacities have been further strengthened. However, access to finance continues to be difficult, and the nonbanking segments of the market need to be further developed, with a view to widen up the funding opportunities for the private sector. Measures should continue to be taken to repair the bank lending channel, including by fostering the clean-up of non-performing loan portfolios (World Bank, 2012b).

\section{LITERATURE REVIEW}

This section presents several studies that use the variable nominal effective exchange rate. Also, here is provided an overview of methods used by these studies (Table 1).

Table-1. Review of methods used in studies which analyze nominal effective exchange rate.

\begin{tabular}{l|l|l|}
\hline Studies & Title & Methods \\
\hline $\begin{array}{l}\text { Baxter and Stockman } \\
\text { (1989). }\end{array}$ & $\begin{array}{l}\text { Business Cycles and the Exchange Rate } \\
\text { Regime: Some International Evidence }\end{array}$ & Correlation analysis \\
\hline Bollerslev (1990) & $\begin{array}{l}\text { Modeling the coherence in short run } \\
\text { nominal exchange rates: A multivariate } \\
\text { generalized ARCH model }\end{array}$ & $\begin{array}{l}\text { SUR, ARCH and GARCH } \\
\text { model }\end{array}$ \\
\hline Flood and Rose (1995) & $\begin{array}{l}\text { Fixing exchange rates :A virtual quest } \\
\text { for fundamentals }\end{array}$ & $\begin{array}{l}\text { Ordinary least squares } \\
\text { method }\end{array}$ \\
\hline Oskooee (2001) & $\begin{array}{l}\text { Nominal and real effective exchange } \\
\text { rates of middle eastern countries and } \\
\text { their trade performance }\end{array}$ & $\begin{array}{l}\text { Dickey-Fuller Unit Root } \\
\text { Tests, Engle-Granger co } \\
\text { integration test and } \\
\text { Johansen co integration test }\end{array}$ \\
\hline $\begin{array}{l}\text { Lai and Lowinger } \\
(2002)\end{array}$ & $\begin{array}{l}\text { Nominal effective exchange rate and } \\
\text { trade balance adjustments in South east } \\
\text { Asia countries }\end{array}$ & $\begin{array}{l}\text { VECM } \\
\text { Tenreyro (2007) }\end{array}$ \\
\hline $\begin{array}{l}\text { On the trade impact of nominal } \\
\text { exchange rate volatility }\end{array}$ & $\begin{array}{l}\text { Poisson pseudo maximum } \\
\text { likelihood model }\end{array}$ \\
\hline Harbinger (2005) & $\begin{array}{l}\text { Nominal Exchange Rate Neutrality: } \\
\text { The Case of Australia }\end{array}$ & VAR model \\
\hline
\end{tabular}

Source: Authors investigation

\section{METHODOLOGY}

Building models with the presence of bilateral causal relationship between two variables, is more complex. The analysis uses the method of ordinary least squares. This method is used for estimation of unknown parameters in the ordinary linear model. This method minimizes the sum of squared vertical distances between observed responses in the data set and the answers provided by the linear approximation. This method characterized estimated ratios that are consistent when regressions are exogenous and there is no perfect multi collinearity. This method can be used to assess linear dependence between phenomena and general model can have one dependent and one or more independent variables. Regressions with the method of least squares, produced highly 
statistically significant parameters, but the presence of autocorrelation question poses the question whether MNC models are robust. ${ }^{1}$ This applies in the case when the variables are co-integrated.

\subsection{Data}

For analysis we use quarterly data which cover the period from 1993 the first quarter, to 2013, first quarter. Data are for the Macedonian economy. Time series are: the nominal effective exchange rate (neer) ${ }^{2}$, observations for this variable are 1993q1 to 2013q1, or 81 observations in total. For real effective exchange rate ${ }^{3}$, we have 81 observation, further Macedonian gross domestic product which also has quarterly observations from 1993 to 2013. Purchasing power parity ${ }^{4}$ is included in the data but this variable has 78 observations for the period $1994 \mathrm{q} 1$, first quarter to 2013q1, first quarter. The interest rate as a time series for the Macedonian economy is represented by the rate of borrowing, and the cover data for it is from 1994q2 (second quarter) to 2013q1 (first quarter), or in total 77 observations. Exports and imports account maximum number of observations, i.e. 81. The data on monetary aggregates M2 and M4 are shorter series $2001 \mathrm{q} 1$ (first quarter) to $2013 \mathrm{q} 1$ (first quarter). The data for the index of inflation or the consumer price index where $2005=100$, all from 1993q1 to 2013 q1, or 81 observation in total. Data were collected from the databases of the International Monetary Fund (IMF) and EconStats ${ }^{\mathrm{TM}} .^{5}$ Further, we show logarithmic levels of the time series.
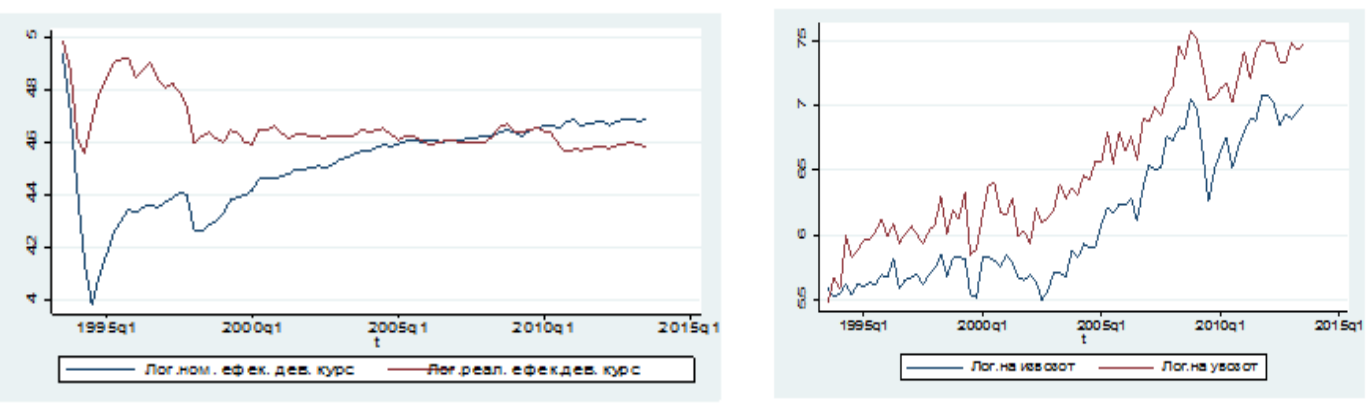

\footnotetext{
${ }^{1}$ While in the presence of autocorrelation of estimated coefficients by the method of least squares remain impartial, consistent and asymptotic normally distributed, they are no longer effective Gujarati (2003).

${ }^{2}$ The nominal effective exchange rate is unadjusted weighted value of the currency of the country to the currencies of all countries with which trade is usually expressed as an index, an index of the currency pool.

${ }^{3}$ The real effective exchange rate is the average of the country's currency to the index basket of other major currencies adjusted for inflation. ${ }^{4} \mathrm{PPP}$ (Purchasing power parity) purchasing power parity is a technique used to detect the relative value of currencies which calculates how big is the change that is needed for the exchange rate to be equal to the purchasing power parity of each currency.

${ }^{5}$ Website for this quote: http://www.econstats.com/ifs/NorGSc_Mac2_Q.htm
} 

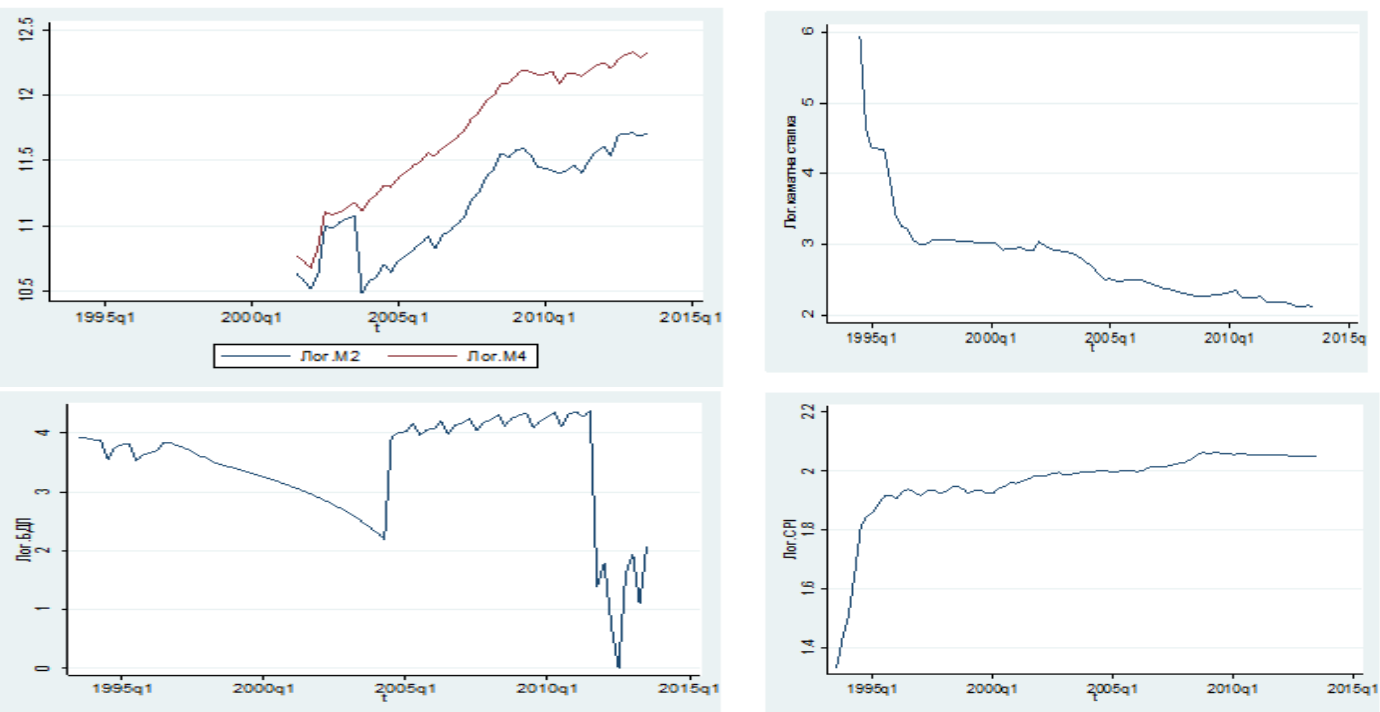

Displaying logarithmic levels of the time series
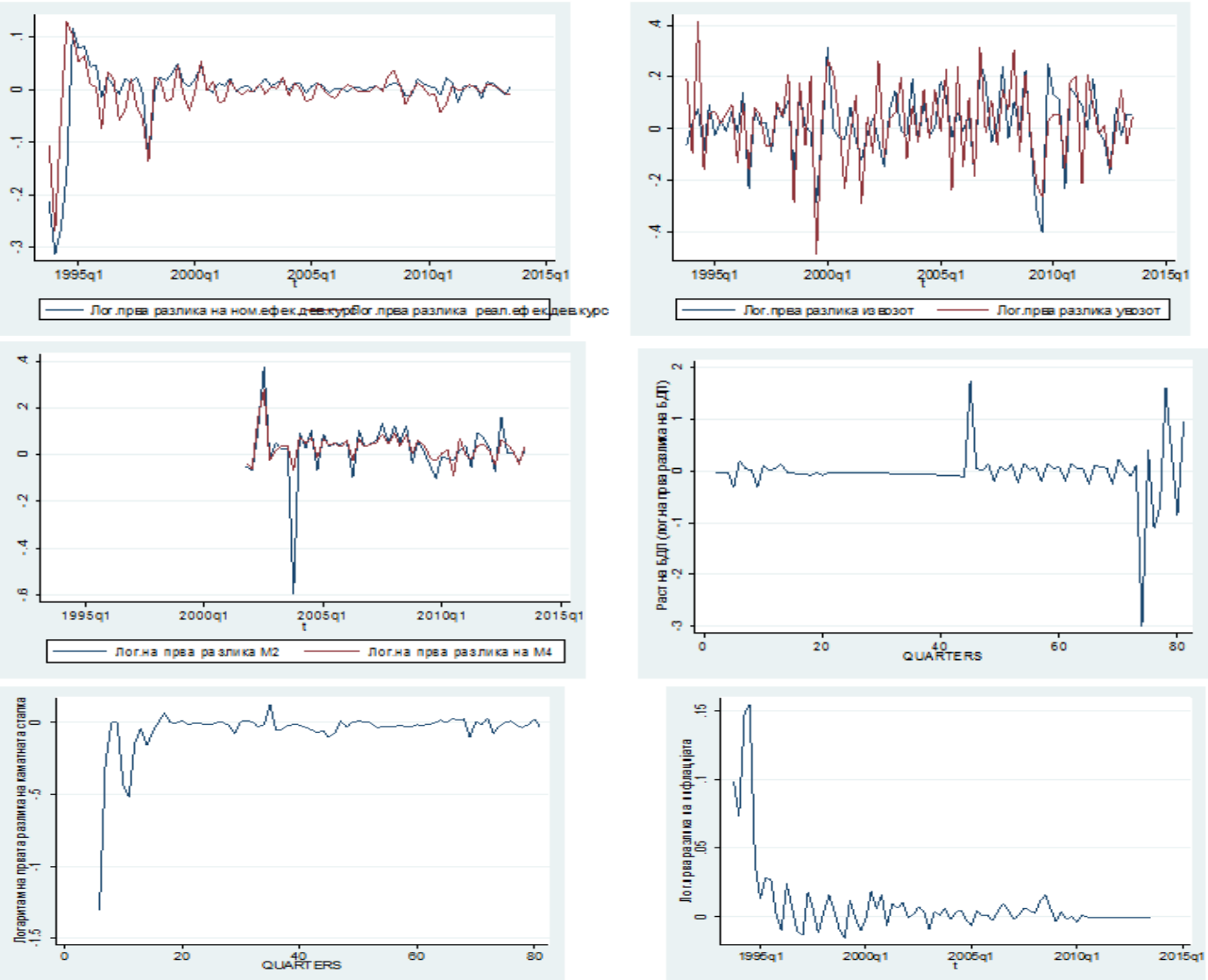

Graphic display of the first difference of the time series as proof that are stationary and integrated in first order i.e. I (1)

\subsection{Empirical Research and Results}

For empirical analysis of the ratio of the nominal effective exchange rate with all other previously mentioned variables in the model, we use quarterly data for Macedonia covering the 
period from 1993 to the first quarter 2013, first quarter. All variables we put in logarithmic form (logneer, logreer, $\operatorname{loggdp}, \log p p p, \log 2, \log 44, \log c$ i, loginterestrate). This is done because the functional form of log-log can examine the elasticity of variables. We agree that coefficients estimated with the method of least squares can not considerstatistically robust because MLS method has the ability to capture cointegrating ratiovariables between two or more variables.

Table-1. MLS models with logarithm of the nominal effective exchange rate as a dependent variable

\begin{tabular}{|c|c|c|c|c|}
\hline \multicolumn{2}{|r|}{ MLS regressions/dependent variable logneer } & $\begin{array}{l}\text { t-statistics(of constant and } \\
\text { independent variable) }\end{array}$ & \multirow{2}{*}{$\begin{array}{c}\begin{array}{c}\text { Ramsey } \\
\text { test }\end{array} \\
0.0003 \\
\end{array}$} & \multirow{2}{*}{ 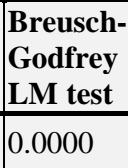 } \\
\hline 1. & logneer $_{\mathrm{t}}=7.077-0.5497 * \operatorname{logreer}_{\mathrm{t}}$ & $\mathrm{t}-$ value $=\{8.71-3.15\}$ & & \\
\hline 2. & $\operatorname{logneer}_{t}=5.091-0.15083 * \operatorname{logppp} t$ & $\mathrm{t}-$ value $=\{13.77-1.58\}$ & 0.6077 & 0.0000 \\
\hline 3. & logneer $_{\mathrm{t}}=4.57-0.17 * \log \mathrm{GDP} \mathrm{t}_{\mathrm{t}}$ & $\mathrm{t}$-value $=\{63.19-0.85\}$ & 0.0000 & 0.0000 \\
\hline 4. & logneer $_{\mathrm{t}}=3.2723+0.1200 * \log \mathrm{M} 2_{\mathrm{t}}$ & $\mathrm{t}$-value $=\left\{\begin{array}{ll}23.9240 & 9.8070\end{array}\right\}$ & 0.3258 & 0.0000 \\
\hline 5. & $\operatorname{logneer}_{\mathrm{t}}=3.3364+0.1089 * \log \mathrm{M} 4_{\mathrm{t}}$ & $\mathrm{t}$-value $=\left\{\begin{array}{ll}62.29 & 23.85\end{array}\right\}$ & 0.0013 & 0.0000 \\
\hline . & logneer $_{t}=5.1119-0.217 *$ loginterestrate $_{t}$ & $\mathrm{t}$ - value $=\{161.029-19.63\}$ & 0.0000 & 0.0000 \\
\hline 7. & $\operatorname{logneer}_{\mathrm{t}}=3.28+0.188 * \operatorname{logimports}_{\mathrm{t}}$ & $\mathrm{t}$-value $=\left\{\begin{array}{ll}20.75 & 7.83\end{array}\right\}$ & 0.0000 & 0.0000 \\
\hline 8. & $\operatorname{logneer}_{\mathrm{t}}=3.21+0.214 * \operatorname{logexports}_{\mathrm{t}}$ & $\mathrm{t}$-value $=\{19.507 .99\}$ & 0.1303 & 0.0000 \\
\hline & $\operatorname{lognee} \mathrm{r}_{\mathrm{t}}=3.82+0.35 * \operatorname{logcp} \mathrm{i}_{\mathrm{t}}$ & $\mathrm{t}$-value $= \begin{cases}13.692 .49\end{cases}$ & 0.0000 & 0.0000 \\
\hline
\end{tabular}

Note: The null hypothesis in Ramsey RESET test is that the model hasn't rejected variables, while the null hypothesis in Breush-Godfrey test is that there is no serial correlation.

From Table 1 we notice that all models suffer from autocorrelation in whose presence the coefficients are still has the best linear unbiased coefficient (BLUE-BEST LINEAR UNBIASED ESTIMATOR), but they are not efficient, which means they have a great variance (standard error), although all coefficients and the constant are statistically significant.

Table-2. MLS models with logarithm of the nominal effective exchange rate as a independent variable

\begin{tabular}{|c|c|c|c|c|}
\hline & MLS regressions/dependent variable logneer & $\begin{array}{c}\text { t-statistics(of constant and independent } \\
\text { variable) }\end{array}$ & Ramsey test & $\begin{array}{c}\text { Breusch- } \\
\text { Godfrey LM test }\end{array}$ \\
\hline 1. & $\operatorname{logreer}_{\mathrm{t}}=5.57-0.203 * \operatorname{logneer}_{\mathrm{t}}$ & $\mathrm{t}-$ value $=\{19.15-3.15\}$ & 0.0000 & 0.0000 \\
\hline 2. & $\operatorname{logppp}_{\mathrm{t}}=4.81-0.21 * \operatorname{logneer}_{\mathrm{t}}$ & $\mathrm{t}-\mathrm{value}=\{8.00-1.58\}$ & 0.0000 & 0.0000 \\
\hline 3. & $\log \operatorname{GDP}_{\mathrm{t}}=4.57-0.18 * \operatorname{logneer}_{\mathrm{t}}$ & $\mathrm{t}-$ value $=\{63.19-0.85\}$ & 0.9653 & 0.0000 \\
\hline 4. & $\operatorname{logM2} \mathrm{t}=3.2723+0.1200 * \operatorname{logneer}_{\mathrm{t}}$ & $\mathrm{t}-$ value $=\{23.929 .81\}$ & 0.0000 & 0.0000 \\
\hline 5. & $\log \mathrm{M} 4_{\mathrm{t}}=3.3364+0.1089 * \operatorname{logneer}_{\mathrm{t}}$ & $\mathrm{t}$ - value $=\left\{\begin{array}{ll}62.290 & 23.85\end{array}\right\}$ & 0.0002 & 0.0000 \\
\hline 6. & loginterestrate $_{\mathrm{t}}=5.12-0.217 * \operatorname{logneer}_{\mathrm{t}}$ & $\mathrm{t}-$ value $=\{161.029-19.63\}$ & 0.0000 & 0.0000 \\
\hline 7. & $\operatorname{logimports}_{\mathrm{t}}=3.28+0.188 * \operatorname{logneer}_{\mathrm{t}}$ & $\mathrm{t}$-value $=\left\{\begin{array}{ll}20.75 & 7.83\end{array}\right\}$ & 0.0000 & 0.0000 \\
\hline 8. & $\operatorname{logexports}_{\mathrm{t}}=-3.31+2.088 * \operatorname{logneer}_{\mathrm{t}}$ & $\mathrm{t}-$ value $=\{19.507 .99\}$ & 0.0000 & 0.0000 \\
\hline 9. & $\operatorname{logcpi} \mathrm{i}_{\mathrm{t}}=1.03+0.2055 * \operatorname{logneer}_{\mathrm{t}}$ & $\mathrm{t}-$ value $=\{2.772 .49\}$ & 0.0000 & 0.0000 \\
\hline
\end{tabular}

Note: The null hypothesis in Ramsey RESET test is that the model hasn't rejected variables, while the null hypothesis in Breush-Godfrey test is that there is no serial correlation. 
The functional form is the best model for the logarithm of the nominal effective exchange rate with the purchasing power parity and the monetary aggregate M2, which is consisted of financial assets that are less liquid than the aggregate M1. The coefficients are interpreted in the usual way, for example, for M2, if the money supply M2 (in Macedonia) grow by $1 \%$, the nominal effective exchange will grow $0.12 \%$.

Table-3.MLS models with first difference of logarithm of the nominal effective exchange rate as a dependent variable.

\begin{tabular}{|c|c|c|c|}
\hline MLS regressions/dependent variable logneer & $\begin{array}{l}\text { t-statistics(of constant and } \\
\text { independent variable) }\end{array}$ & $\begin{array}{c}\text { Ramsey } \\
\text { test }\end{array}$ & $\begin{array}{c}\text { Breusch- } \\
\text { Godfrey } \\
\text { LM test }\end{array}$ \\
\hline 1. $\Delta$ logneer $r_{t}=0.011-0.847 * \Delta$ logree $_{\mathrm{t}}$ & $\mathrm{t}-$ value $=\{0.227 .38\}$ & 0.0000 & 0.0000 \\
\hline 2. $\quad \Delta \operatorname{logneer} r_{\mathrm{t}}=0.0068-0.062 * \Delta \operatorname{logppp}_{\mathrm{t}}$ & $\mathrm{t}-$ value $=\{11.79-0.74\}$ & 0.0067 & 0.9182 \\
\hline 3. $\quad \Delta \operatorname{lognee} r_{\mathrm{t}}=-0.0029+0.0066 * \Delta \log \mathrm{GDP}_{\mathrm{t}}$ & $\mathrm{t}$-value $=\left\{\begin{array}{ll}-0.42 & 0.47\end{array}\right\}$ & 0.8553 & 0.0000 \\
\hline 4. $\quad \Delta \operatorname{logneer} r_{t}=0.0039-0.004 * \Delta \log M 2_{t}$ & $\mathrm{t}-$ value $=\{2.76-0.35\}$ & 0.2384 & 0.4548 \\
\hline 5. $\quad \Delta$ logneer $r_{t}=0.0033+0.016 * \Delta \log M 4_{t}$ & $\mathrm{t}-$ value $=\left\{\begin{array}{ll}2.07 & 0.70\end{array}\right\}$ & 0.3055 & 0.5282 \\
\hline 6. $\quad \Delta$ lognee $_{\mathrm{t}}=0.006-0.072 * \Delta$ loginterestrate $_{\mathrm{t}}$ & $\mathrm{t}$-value $=\{1.90-4.32\}$ & 0.1538 & 0.0246 \\
\hline 7. $\Delta$ llogneer $_{\mathrm{t}}=-0.0022-0.02 * \Delta$ logimports $_{\mathrm{t}}$ & $\mathrm{t}$ - value $=\{-0.37-0.48\}$ & 0.0003 & 0.0000 \\
\hline 8. $\quad \Delta$ lognee $r_{\mathrm{t}}=-0.0035+0.025 * \Delta$ logexports $_{\mathrm{t}}$ & $\mathrm{t}-$ value $=\left\{\begin{array}{lll}-0.50 & 0.48\end{array}\right\}$ & 0.8235 & 0.0000 \\
\hline 9. $\quad \Delta \operatorname{logneer} r_{t}=0.011-1.53 * \Delta \operatorname{logcpi} i_{t}$ & $\mathrm{t}-$ value $=\{2.02-8.53\}$ & 0.0000 & 0.0000 \\
\hline
\end{tabular}

Note: The null hypothesis in Ramsey RESET test is that the model hasn't rejected variables, while the null hypothesis in Breush-Godfrey test is that there is no serial correlation.

Table-4. MLS models with first difference of logarithm of the nominal effective exchange rate as a independent variable

\begin{tabular}{|c|c|c|c|c|}
\hline \multicolumn{2}{|r|}{ MLS regressions/dependent variable logneer } & $\begin{array}{l}\text { t-statistics (of constant and } \\
\text { independent variable) }\end{array}$ & \multirow{2}{*}{$\begin{array}{c}\begin{array}{c}\text { Ramsey } \\
\text { test }\end{array} \\
0.0000\end{array}$} & \multirow{2}{*}{$\begin{array}{c}\begin{array}{c}\text { Breusch- } \\
\text { Godfrey } \mathbf{L M} \\
\text { test }\end{array} \\
0.0246\end{array}$} \\
\hline 1. & $\Delta$ logree $r_{\mathrm{t}}=-0.0035-0.48 * \Delta \operatorname{logneer}_{\mathrm{t}}$ & $\mathrm{t}$-value $=\{-0.887 .38\}$ & & \\
\hline 2. & $\Delta \operatorname{logppp}_{t}=-0.0023-0.1152 * \Delta$ logneer $_{\mathrm{t}}$ & $\mathrm{t}-$ value $=\{-0.45-0.74\}$ & 0.1799 & 0.0316 \\
\hline 3. & $\Delta \log \mathrm{GDP}_{\mathrm{t}}=-0.021+0.42 * \Delta$ logneer $_{\mathrm{t}}$ & $\mathrm{t}$-value $=\left\{\begin{array}{ll}-0.39 & 0.47\end{array}\right\}$ & 0.8864 & 0.1155 \\
\hline 4. & $\Delta \log \mathrm{M} 2_{\mathrm{t}}=0.0248-0.64 * \Delta \log n e e \mathrm{r}_{\mathrm{t}}$ & $\mathrm{t}-$ value $=\{1.30-0.35\}$ & 0.2814 & 0.5973 \\
\hline 5. & $\Delta \operatorname{logM} 4_{t}=0.033+0.629 * \Delta$ logneer $_{\mathrm{t}}$ & $\mathrm{t}$-value $=\left\{\begin{array}{ll}3.24 & 0.70\end{array}\right\}$ & 0.2827 & 0.8024 \\
\hline 6. & $\Delta$ loginterestrate $_{t}=-0.024-2.78 * \Delta$ logneer $_{t}$ & $\mathrm{t}$-value $=\{-1.33-4.32\}$ & 0.0000 & 0.1718 \\
\hline 7. & $\Delta \operatorname{logimports}_{\mathrm{t}}=0.024-0.143 * \Delta$ logneer $_{\mathrm{t}}$ & $=\left\{\begin{array}{ll}1.33 & -0.48\end{array}\right\}$ & 0.0843 & 0.0002 \\
\hline 8. & $\Delta \operatorname{logexports}_{\mathrm{t}}=0.019+0114 * \Delta$ logenee $_{\mathrm{t}}$ & $\mathrm{t}-$ value $=\left\{\begin{array}{ll}1.23 & 0.48\end{array}\right\}$ & 0.8494 & 0.4061 \\
\hline 9. & $\Delta \operatorname{logcpi} i_{t}=0.007-0.315 * \Delta$ lognee $r_{t}$ & $\mathrm{t}-$ value $=\{3.51-8.53\}$ & 0.0000 & 0.0000 \\
\hline
\end{tabular}

Note: The null hypothesis in Ramsey RESET test is that the model hasn't rejected variables, while the null hypothesis in Breush-Godfrey test is that there is no serial correlation.

According Ramsey test, the best model is, where $t$ statistics are $\mathrm{t}-$ вредности $=\{63.19-0.85\}$ (Table 2). All models also suffer from serial correlation. The 
coefficients are almost all highly statistically significant, but statistically ineffective because of the presence of serial correlation. In the following two tables we present the above functional forms but with differentiated variables (first difference) (Tables 3 and 4). From the Table 3 it is notable that the functional form in regressions with differentiated series is much better than that when are in the level, $p$ value is much greater than zero and this means that it's statistically significant. Also serial correlation 4 of 9 models is not a problem unlike the two previous tables where the serial correlation was a problem in any of the models. Table 4 presents models with the first difference of the nominal effective exchange rate. With models, where the nominal effective exchange rate is a dependent variable, in 6 of 9 models the functional form is good, which means models do not suffer from a bias to rejected variables. Serial correlation is a problem according Breusch-Godfrey LM test when the first difference of logarithm of the consumer price index is dependent variable and when the growth of exports is dependent variable. Other equations according this test don't suffer from serial correlation. In the table 5 based on the results of the above equations we present the causal tests of the nominal effective exchange rate with other variables for which we have data.

Table-5. Models of causality in Macedonia based on the Method of Least Squares

\begin{tabular}{|c|c|c|}
\hline & Log-level & First difference \\
\hline $\begin{array}{l}\text { Nominal effective exchange rate } \\
\text { (neer) and Real effective exchange } \\
\text { rate (reer) }\end{array}$ & $\operatorname{logneer}_{\mathrm{t}} \Leftrightarrow \operatorname{logree}_{\mathrm{t}} *$ & $\Delta \operatorname{lognee} r_{\mathrm{t}} \Leftrightarrow \Delta \operatorname{logree}_{\mathrm{t}} *$ \\
\hline $\begin{array}{l}\begin{array}{l}\text { Nominal effective exchange rate } \\
\text { (neer) and Purchasing Power } \\
\text { Parity (ppp) }\end{array} \\
\end{array}$ & $\operatorname{logneer}_{\mathrm{t}} \Leftrightarrow \operatorname{logppp}_{\mathrm{t} *}$ & $\Delta \operatorname{lognee}_{\mathrm{t}} \Leftrightarrow \Delta \operatorname{logpp} \mathrm{p}_{\mathrm{t}}$ \\
\hline $\begin{array}{l}\text { Nominal effective exchange rate } \\
\text { (neer) and Gross Domestic } \\
\text { Product (GDP) }\end{array}$ & $\operatorname{logneer}_{\mathrm{t}}-\operatorname{loggdp_{t}}$ & $\Delta \operatorname{lognee} r_{\mathrm{t}}-\Delta \operatorname{loggdp} \mathrm{p}_{\mathrm{t}}$ \\
\hline $\begin{array}{l}\text { Nominal effective exchange rate } \\
\text { (neer) andM2 Monetary aggregate } \\
\text { (M2) }\end{array}$ & $\operatorname{lognee}_{\mathrm{t}} \Leftrightarrow \log \mathrm{M} 2_{\mathrm{t}} *$ & $\Delta \log n e e r_{\mathrm{t}}-\Delta \log \mathrm{M} 2_{\mathrm{t}}$ \\
\hline $\begin{array}{l}\text { Nominal effective exchange rate } \\
\text { (neer) and M4 Monetary aggregate } \\
\text { (M4) }\end{array}$ & $\operatorname{logneer}_{\mathrm{t}} \Leftrightarrow \log \mathrm{M} 4_{\mathrm{t} *}$ & $\Delta \log n e e r_{\mathrm{t}}-\Delta \log \mathrm{M} 4_{\mathrm{t}}$ \\
\hline $\begin{array}{l}\text { Nominal effective exchange rate } \\
\text { (neer) and interest rate (interest } \\
\text { rate) }\end{array}$ & lognee $_{\mathrm{t}} \Leftrightarrow$ loginterestrate $_{\mathrm{t}} *$ & $\Delta$ logneer $_{\mathrm{t}} \Leftrightarrow \Delta$ loginterestrate $_{\mathrm{t}} *$ \\
\hline $\begin{array}{l}\text { Nominal effective exchange rate } \\
\text { (neer) and imports (imports) }\end{array}$ & logneer $_{\mathrm{t}} \Leftrightarrow \log$ imports $_{t} *$ & $\Delta \operatorname{logneer}_{\mathrm{t}}-\Delta \operatorname{logimports}_{\mathrm{t}}$ \\
\hline
\end{tabular}

Table-5.(Continued) Models of causality in Macedonia based on the Method of Least Squares

\begin{tabular}{|c|c|c|}
\hline $\begin{array}{l}\text { Nominal effective exchange rate } \\
\text { (neer) and exports(exports) }\end{array}$ & $\operatorname{lognee}_{t} \Leftrightarrow \log \exp$ orts $_{t} *$ & $\Delta$ logneer $-\Delta$ logexports \\
\hline $\begin{array}{l}\text { Nominal effective exchange rate } \\
\text { (neer) and Consumer price index } \\
\text { (CPI) }\end{array}$ & $\operatorname{lognee}_{\mathrm{t}} \Leftrightarrow \log c p i_{t *}$ & $\Delta$ logneer $\Leftrightarrow \Delta \log \mathrm{cpi} *$ \\
\hline
\end{tabular}

Note: $\Longleftrightarrow$ show bilateral causal ratio, - indicates lack of causality, *denotes statistical significance of the relationship between the variables of $10 \%$. 
The previous tests of causality, we underline that emphasize that undermines confidence autocorrelation disrupts the confidence in coefficients estimated by the Method of Least Squares, even it can destroy. However, the purpose of theregressions with the Method of Least Squares is testing the ratio of nominal effective exchange rate as a variable with other variables in the model, and can be concluded that there is causality.

\section{DISCUSSION}

The main goal of National Bank of Republic of Macedonia is the maintenance of the price stability. Regarding this, the National Bank is committed to apply a strategy for maintaining stable nominalexchange rate against the Euro. The role of the exchange rate as a nominal anchor derivesfrom the characteristics of the domestic economy, as a small and open economy that ishighly dependent on the import of primary commodities (European Commission, 2007). Also, Macedonian exchange rate can be used as an instrument for export performances of the country. According to the expectations from reports by NBRM, the inflation will slow down in 2015 as well, whenthe historical average and equal $2 \%$ will be approached.Also, in 2015 , it is expected that the currentpublic investments will continue, according to the expectations for new infrastructureprojects (NBRM, 2014). It is estimated that these developments in the export sector and the strengtheningof investment activity will create positive transmission effects on both the labor market andthe expectations, and thus be a factor for further increase in the household consumption. Itis expected that the GDP growthin 2015 would speed up rapidly and reach $4.4 \%$.Giventhe high openness of the economy, the risks to the projected growth continued to resultfrom the global environment and developments in the external environment. By the end of 2015 , the creditgrowth is projected to accelerate and it would reach 8.5\%. Projections for 2015 show that the external position can provide furtherincrease in the foreign reserves and their maintenance at appropriate level. In addition, in 2015, wideningof the current account deficit by $5.7 \%$ of GDP isexpected, mainly due to the fall in private transfers. Despite the moderate deterioration on the current account,it is estimated that its negative balance will be fully financed by capital inflows, mainlycoming from foreign direct investment and external borrowings for infrastructure projects. In 2015, prudent fiscal policy is expected with gradual consolidationof the budget deficit and relatively stable level of public debt. The fiscal policy is importantfactor that influence the monetary policy setup, while the adequate coordination of thesepolicies is crucial for creation and maintenance of the macroeconomic stability. Hence, in 2015, it would equal $3.2 \%$ of the GDP. The primary budget deficit should be equal $2.2 \%$ of the GDP in 2015, respectively.

According the above estimations, Macedonian policymakers should create policy with several aims focused on exchange rate policy because:

- A competitive real exchange rate provides an incentive for exports

- The impact of exchange rates on trade should be seen in the context of continued integration of supply chains 
- Exports generally include high import content and impact of foreign currency-exchange appreciation or depreciation on any finished product because it is complex. If the depreciation of the exchange rate makes its exports of finished products "cheaper", it makes imported components "expensive" for domestic producers.

- Maintaining growth and reducing the unemployment in a small and open economy such as Macedonia depends from improved performance of exports.

- Improving the performance of exports can help to preserve macroeconomic stability by closing the gap in the current account to avoid wasting supplies and to stop the growth of external debt.

- Improving performance requires improving export competitiveness.

- An outward oriented, market-friendly trade regime, which emphasizes the dismantling of import controls and tariffs (permitting access to inputs at world prices), and streamlined bureaucratic procedures, i.e. export and import procedures, modern customs administration and efficient value added tax administration will facilitate exports, including from SMEs.

\section{CONCLUSION}

How could Macedonia reach and sustain higher rates of economic growth thus speeding up the process of economic convergence too?

The research offer options that include increase of the labor contribution to economic growth by raising labor participation and reducing unemployment. The second option refers to the improvement of allocative efficiency. This considers promotion of enterprise restructuring and reforming product market regulation as including regulation in the infrastructure sector. Next option is focused on deepening trade integration by promoting export-oriented FDI and developing the supply of exportable goods, meaning that Macedonia would need to integrate its logistics infrastructure. Accelerating the process of economic convergence will be supported by fostering technological progress. The recommendations are focused on policy-makers, inviting them to identify what policies are politically feasible and to be checked for their consistency with the overall objective of raising and sustaining economic growth. Next, these strategies need to generate institutional requirements that are commensurate with the existing institutional endowment of Macedonia. This will lead to a near-term focus on deepening trade integration and fostering innovation, while measures related to expanding labor participation and employment could be adopted more gradually with a long-term perspective. These measures would better position the country to fully benefit from EU Accession and to better manage the effects of the global financial crisis, by strengthening Macedonia's international competitiveness.

In a situation where the competitive price is appropriate, further performance gains in exports may be hampered by structural factors. The real exchange rate depreciated steadily and Macedonian price level is low when it is compared to other countries with similar income. Although estimation of the equilibrium real exchange rate is challenging, measurements show that 
the exchange rate is generally in line with macroeconomic fundamentals. In contrast, direct comparison of wages between countries suggests problem with the cost competitiveness, while heterogeneity of data makes this comparison quite difficult. Macedonian producers fail to maintain or increase their share in exports.

According to results, we conclude that the cointegration relation of the nominal effective exchange rate is bilateral with following macroeconomic aggregates: interest rate, purchasing power parity, the real effective exchange rate (REER) and the monetary aggregate M2. The cointegration relation has direction from the nominal effective exchange rate to other macroeconomic aggregates only in the case of imports and inflation. In the case of monetary aggregate M4 and exports, causality moves from them to the nominal effective exchange rate. In the case of the GDP, the serie is not cointegrated with the nominal effective exchange rate. Based on the results we can decide to favor long-term bilateral causal relationship. The series of short term are not statistically significant related to the short-term.

With support of the estimations we showed that in a small and open economy such as Macedonia, using real exchange rate as an instrument could be realized the opportunity for growth of export performances, increase aggregate demand and increasing economic growth thus speeding the convergence process to EU. So, exchange rate can be seen not only as an instrument for maintaining price stability but also as an instrument that will contribute for economic stability of Macedonia and strengthening the stability of the financial system.

\section{REFERENCES}

Baxter, M. and A. Stockman, 1989. Business cycles and the exchange rate regime: Some international evidence. Journal of Monetary Economics North-Holland, 23(3): 377-400.

Bisev, G. and M. Petkovski, 2003. FYR Macedonia - challenges for economic recovery. Prepared for the Conference Organised by the Peace and Crisis Management Foundation, Cavtat Croatia.

Bollerslev, T., 1990. Modeling the coherence in short-run nominal exchange rates: A multivariate generalized ARCH model. Review of Economics and Statistics, 72(3): 498-505.

Dauti, B. and P. Pollozhani, 2008. Economic challenges for Macedonian economy toward European union integration. SEEU Review, 4(2): 141-164.

De, G.P. and G. Schnabl, 2004. Exchange rate regimes and macroeconomic stability in central and Eastern Europe. Mimeo: Catholic University of Leuven.

De, S.R. and B. Gerard, 2006. Financial integration, international portfolio choice, and the European monetary union. ECB Working Paper No. 626.

Edwards, S., 1998. Openness, productivity and growth: What do we really know? Economic Journal, 108(2): 383-398.

European Commission, 2007. The EU economy 2007 review, moving Europe's productivity frontier. Available from http://ec.europa.eu/economy_finance/publications/publication10130_en.pdf.

Fidrmuc, J., 2004. The endogeneity of optimal currency area criteria, intra-industry trade and EMU enlargement. Contemporary Economic Policy, 22(1): 1-12. 
Flood, R.P. and A.K. Rose, 1995. Fixing exchange rates. A virtual quest for fundamentals. Journal of Monetary Economics, 36(1): 3-37.

Grigonyte, D., 2004b. The impact of fiscal policy on risk premia in central and East European countries. Mimeo: ZEI University of Bonn.

Gujarati, D.N., 2003. Basic econometrics. 4th Edn., New York: McGraw Hill.

Habermas, J., 2012. The crisis of the European union. A response. Cambridge: Polity Press, Trad. Ciaran Cronin.

Harbinger, A.W., 2005. Nominal exchange rate neutrality: The case of Australia. Armidale, NSW 2351: University of New England.

Holtemoller, O., 2005. Uncovered interest rate parity and analysis of monetary convergence of potential EMU accession countries. International Economics and Economic Policy, 2(1): 33-63.

Joseph, E.P. and H.R. Bruce, 2008. Making Bosnia work: Why EU accession is not enough. USI Peace Briefing. Available from http://www.usip.org/publications/making-bosnia-work-why-eu-accessionnot-enough.

Lai, A. and T. Lowinger, 2002. Nominal effective exchange rate and trade balance adjustment in South Asia countries. Journal of Asian Economics, 13(3): 371-383.

NBRM, 2014. Recent macroeconomic indicators. Review of the Current Situation. Available from http://nbrm.mk/?ItemID=B9701F65DF112443A3220275D11AC18E.

Oskooee, B.M., 2001. Nominal and real effective exchange rates of Middle Eastern countries and their trade performance. Applied Economics, 33(1): 103-111.

Schadler, S., P. Drummond, L. Kuijs, Z. Murgasova and E.R. Van, 2005. Euro adoption in the accession countries: Vulnerabilities and strategies. In S. Schadler Eds., Euro adoption in central and Eastern Europe: Opportunities and challenges. Washington, DC: International Monetary Fund. pp: 147-80.

Sedelmeier, U., 2006. Europeanisation in new member and candidate states. Living Rev. Euro. Gov, 1(3): 134.

Tenreyro, S., 2007. On the trade impact of nominal exchange rate volatility. Journal of Development Economics, 82(2): 485-508.

World Bank, 2012b. Golden growth, restoring the lustre of the European economic model. Washington, DC: World Bank.

World Bank, 2013c. Global economic prospects June 2013: Looking for stable ground. Washington, DC: World Bank. 